"Alexandre le "circumnavigateur" dans le roman persan de Tarsusi ", in : François de Polignac, éd., Alexandre le Grand, figure de l'incomplétude. Actes de la Table ronde de la fondation Hugot du Collège de France (31 mai 1997), Mélanges de L'Ecole française de Rome, Moyen Âge, t. 112 (2000), 1, pp. 97-112.

\title{
Marina Gaillard
}

\section{OpenEdition \\ Journals}

Édition électronique

URL : http://journals.openedition.org/abstractairanica/35818

DOI : 10.4000/abstractairanica.35818

ISSN : 1961-960X

Éditeur :

CNRS (UMR 7528 Mondes iraniens et indiens), Éditions de l'IFRI

Édition imprimée

Date de publication : 15 mai 2002

ISSN : 0240-8910

\section{Référence électronique}

Marina Gaillard, « "Alexandre le "circumnavigateur" dans le roman persan de Tarsusi », in : François de Polignac, éd., Alexandre le Grand, figure de l'incomplétude. Actes de la Table ronde de la fondation Hugot du Collège de France (31 mai 1997), Mélanges de L'Ecole française de Rome, Moyen Âge, t. 112 (2000), 1, pp. 97-112. », Abstracta Iranica [En ligne], Volume 23 | 2002, document 278, mis en ligne le 08 février 2010, consulté le 25 septembre 2020. URL : http://journals.openedition.org/abstractairanica/35818 ; DOI : https://doi.org/10.4000/abstractairanica.35818 
"Alexandre le "circumnavigateur" dans le roman persan de Tarsusi ", in : François de Polignac, éd., Alexandre le Grand, figure de l'incomplétude. Actes de la Table ronde de la fondation Hugot du Collège de France (31 mai 1997), Mélanges de L'Ecole française de Rome, Moyen Âge, t. 112 (2000), 1, pp. 97-112.

Marina Gaillard

Dans cet article dense sont abordées quelques-unes des questions majeures que suscite la lecture d'un récit aussi riche qu'original, le Dārāb-nāme d'Abū Ṭāher Ṭarsūsī (12 ${ }^{\mathrm{e}} \mathrm{s}$.), ouvrage en prose peu connu qui consiste pour une part en un "roman d'Alexandre ». Sur le plan de la cosmographie et de la navigation, l'étude met en évidence les informations communes à ce récit et au 'Ajāyeb-nāme de Mohammad Hamadānī (v. Abs. Ir., 20-21, n638), lesquelles laissent à penser que les deux ouvrages auraient pu puiser à une même source. L'A. s'attache aussi à retracer le périple d'Alexandre et à situer géographiquement certaines de ses étapes (par ex. la Source de vie), comme à identifier les lieux qui jalonnent la vie du roi. En soulignant la place éminente tenue par les sages et le rôle de premier plan qu'ils jouent, ainsi que la dépendance, d'ailleurs mal tolérée, d'Alexandre à leur égard, il met un accent nouveau et original sur l'aspect 
«savant» du récit du point de vue des techniques et des sciences. L'image peu glorieuse et peu héroïque d'un Alexandre présomptueux, auquel seule sa mission de conquérant musulman permet de recouvrer sa grandeur, contraste avec la dimension de celle qui deviendra sa femme, Būrān-DoHnt (Roxane), « l'Iranienne ». Mais son périple terrestre inachevé ne lui permet pas d'atteindre à la fonction de cosmocrator, et son œuvre de conversion des peuples à l'Islam reste limitée : il n'a plus ni le rôle du « conquérant universel », ni celui d'un " prophète éternel ».

INDEX

Thèmes : 11.1.1. Littérature persane classique

\section{AUTEURS}

MARINA GAILLARD

CNRS - Paris 